Moustafa S. Darweesh et al., Analysis of different protection methods against water hammer on water supply network (case study-Assiut city network), pp. $2021-2035$

\title{
ANALYSIS OF DIFFERENT PROTECTION METHODS AGAINST WATER HAMMER ON WATER SUPPLY NETWORK (CASE STUDY-ASSIUT CITY NETWORK)
}

\author{
Nashat A. Ali, Gamal Abozeid and Moustafa S. Darweesh * \\ Staff in Civil Eng. Dept., Assuit University, 71516 Assuit
}

Received 3 September 2013; accepted 27 September 2013

\begin{abstract}
The effect of using different protection devices on water hammer phenomenon to provide an acceptable level of protection against system failure due to pipe collapse or bursting is presented. Water Hammer and Mass Oscillation (WHAMO) software is used in the analysis which uses the implicit finite difference scheme for solving the momentum and continuity equations at unsteady state case. Assiut city water supply network is used. The network is supplied from two points at pump No. 36 and pump No. 37. Flow of pipe network is studied under steady normal case, without any protection case against water hammer phenomenon, and the model under different operation cases; with a transient protection device(s) such as non-return valve, open surge tank, air chamber and pressure relief valve (PRV). The results are performed for three scenarios; the first is the normal operation of pump 36 and failure of pump 37, the second is the normal operation of pump 37 and failure of pump 36, and finally failure of pumps 36 and 37 together. The results showed that using of open surge tank or air chamber with non-return valve protects the pipe network effectively from the harm of water hammer. Also, using PRV with non-return valve protects the pipe network from extreme pressures. Although using non-return valve only doesn't have a great effect on the maximum pressure head than the normal case, it protects the network from the more low pressures than without protection one. All protection cases safeguard the pipe network from the extremes of water hammer, but increase the water hammer wave period. Finally, the sudden shut down of the pumps 36 and 37 together has the large effect on the pressure heads than the shut down of any of them only.
\end{abstract}

Keywords: Water Hammer, Pipes Network, Protection devices, Assiut city.

\section{Introduction}

The abrupt change to the flow that causes large pressure fluctuations is called water hammer. The name comes from the hammering sound that sometimes occurs during the phenomenon (Parmakian [17]). Water hammer phenomenon has received an attention in the past few decades [1-7, 9, 12 and 14]. Choon et al. [7] conducted experiments in pipeline system with different pipe material, length, diameter and pressure in pipeline in order to investigate the water hammer effect. They found that, the water hammer effect in the PVC pipe is greater than that in steel pipe, the high pressure pipeline produce more water hammer effect. Also, they found that, the lower strength material, smaller inlet diameter pipe, and longer pipe has lager water hammer. Watters et al. [20] performed an experimental program of measuring water-hammer wave velocities and pressure increments to determine how well classical elastic theory of hydraulic transients predicts these quantities in pipe made of polyvinyl chloride (PVC) and reinforced plastic. Their experimental data were found to agree well with the theoretical calculations. Abozeid et al.

\footnotetext{
* Corresponding author.

E-mail address:eng_taftaf82@yahoo.com
} 
Moustafa S. Darweesh et al., Analysis of different protection methods against water hammer on water supply network (case study-Assiut city network), pp. $2021-2035$

[2] investigated the effect of sudden contractions and enlargement on transient flow in pipeline system due to pump shut down. They found that the increase of pipe contraction or enlargement ratios increase the effect of pump shut down on both fluctuation of piezometric heads, values and directions of flow rates. Mohamed and Gad [15] studied the effect of pipes networks' simplification on water hammer phenomenon. They reported that, the hydraulic equivalence simplifications increase the transient pressure and flow rate in the simplified network according the degree of simplification. Lohrasbi and Attarnejad [12] described the physical phenomenon of water hammer and the mathematical model which provides the basis for design computations using the method of characteristics and effect of valve opening and closure. It has been shown that the more rapid of the closure of the valve, the more rapid is the change in momentum. Ali et al. [3] investigated protection of single pipeline by non-return valve, open surge tank and air chamber. They stated that, although the non-return valve protects the pump from water hammer, it increases the transient pressure heads. The open surge tank or air chamber protects the pipeline from negative pressures as well as the positive pressures. Friedman et al. [10] studied the control of pressure transients by air-vacuum valves. They found that, the installation of air-vacuum valves throughout the system offers some protection against negative pressures but they are not effective as surge tanks. Kim [11] modeled some surge protection devices, such as surge tanks and air chambers, with the impulse response method (IRM) to examine the method of characteristics (MOC). His transient analysis shows that the IRM results match those of simulations of (MOC) in the presence of the hydraulic device. Larger pumps have more inertia because they have more rotating mass. Pumps with higher inertias can help to control transients because they continue to move water through the pump for a longer time as they slowly decelerate (Magzoub and Kwame [13]). Niţescu et al. [16] studied asymmetrical hydraulic resistance devices, and stated that, these devices efficiency are proved not only by the harmless pressure in the installation during the water hammer, but also by the reduced water change flow rate between the chamber and the discharge duct. Air vessels generally alleviate negative pressures more effectively than other forms of water hammer protection, and they can maintain a positive pressure in the line at all stages following pump trip (Stephenson [19]).

According to the aforementioned studies, water hammer in pipes networks has little attention from the investigators. However, every water supply network has its own special characteristics which makes it different from the other networks. Also, due to a lack of field measurements which are costly, it becomes important to use numerical models to gain an indication about the behavior of network under transient effect. Present study is performed to investigate the effect of sudden shut down of pumps on transient pressure heads and flow rates with different protection cases for Assiut city water supply network.

\section{Theoretical Considerations}

Because of difficulty in solution of governing equations, engineers in pipelines design usually neglect this phenomenon. Recently, a number of numerical methods suitable for digital computer analyses have been reported in the literature, which may be used to solve these equations (Chaudhry and Yevjevich [6]). In the following, the governing equations are solved by one of these methods.

Journal of Engineering Sciences, Assiut University, Faculty of Engineering, Vol. 41, No. 6, November, 2013, E-mail address: jes@aun.edu.eg 
Moustafa S. Darweesh et al., Analysis of different protection methods against water hammer on water supply network (case study-Assiut city network), pp. $2021-2035$

\section{Governing Equations for Unsteady Flow in Pipelines}

The governing equations for unsteady flow in pipeline are derived under the following assumptions; (1) one dimensional flow i.e. velocity and pressure are assumed constant at a cross section; (2) the pipe is full and remains full during the transient; (3) no column separation occurs during the transient; (4) the pipe wall and fluid behave linearly elastically; and (5) unsteady friction loss is approximated by steady-state losses.

The unsteady flow inside the pipeline is described in terms of unsteady mass balance (continuity) equation and unsteady momentum equation, which define the state of variables of V (velocity) and P (pressure) given as Simpson and Wu [18];

$$
\begin{aligned}
& \frac{\partial \rho}{\partial t}+V \frac{\partial \rho}{\partial x}+\rho \frac{\partial V}{\partial x}+\frac{\rho}{A} \frac{d A}{d t}=0 \\
& \frac{\partial V}{\partial t}+V \frac{\partial V}{\partial x}+\frac{1}{\rho} \frac{\partial P}{\partial x}-g \sin \alpha+\frac{f|V| V}{2 D}=0
\end{aligned}
$$

Where $\mathrm{x}=$ distance along the pipeline; $\mathrm{t}=$ time $; \mathrm{V}=$ velocity; $\mathrm{P}=$ hydraulic pressure in the pipe; $\mathrm{g}=$ acceleration due to gravity; $\mathrm{f}=$ Darcy-Weisbach friction factor; $\rho$ = fluid density; $\mathrm{D}=$ pipe diameter; $\alpha=$ pipe slope angle, and $\mathrm{A}=$ cross sectional area of the pipe.

Equation (1) is the continuity equation and takes into account the compressibility of water and the flexibility of pipe material. Equation (2) is the equation of motion. In Eq. (1), the terms $\frac{1}{\rho}\left(\frac{\partial \rho}{\partial t}+\frac{\partial \rho}{\partial x} V\right)$ are replaced by equivalent $\frac{1}{\rho} \frac{d \rho}{d t}$ where $V=\frac{d x}{d t}, \frac{d \rho}{d t}=\frac{\rho}{K} \frac{d P}{d t}$, and $\mathrm{K}$ is the bulk modulus of the fluid. Also, the fourth term in Eq. (1) can be expressed as $\left(1-v^{2}\right) \frac{\rho D}{e E} \frac{d P}{d t}$, where $v$ is the poison's ratio of the pipe, e is the pipe wall thickness and $\mathrm{E}$ is the Young's modulus of elasticity of the pipe. Substitution by these abbreviations in Eq. (1), it can be reduced to the following formula;

$$
\frac{d P}{d t}\left[\frac{1}{K}+\left(\frac{1-v^{2}}{E}\right) \frac{D}{e}\right]+\frac{\partial V}{\partial x}=0
$$

Wave speed can be defined as the time taken by the pressure wave generated by instantaneous change in velocity to propagate from one point to another in a closed conduit. Wave speed (c) can be expressed as;

$$
\frac{1}{\rho c^{2}}=\left[\frac{1}{K}+\left(\frac{1-v^{2}}{E}\right) \frac{D}{e}\right]=\frac{1}{K}\left[1+\frac{K c_{1} D}{E e}\right]
$$

Where: $C_{1}=\left(1-v^{2}\right)$. Substitution by Eq. (4) into Eq. (3) and dividing the result by $\gamma$ yields;

$\left[\frac{\partial H}{\partial t}+\frac{\partial H}{\partial x} V\right]+\frac{c^{2}}{g} \frac{\partial V}{\partial x}=0$

Journal of Engineering Sciences, Assiut University, Faculty of Engineering, Vol. 41, No. 6, November, 2013, E-mail address: jes@aun.edu.eg 
Moustafa S. Darweesh et al., Analysis of different protection methods against water hammer on water supply network (case study-Assiut city network), pp. 2021 - 2035

Where $\mathrm{H}$ is the piezometric head, i.e. pressure head plus the elevation head. The term $\frac{\partial H}{\partial x}$ is small compared to $\frac{\partial H}{\partial t}$ and it is often neglected. Thus the simplified form of the continuity equation in terms of discharge, Eq. (5) becomes;

$\frac{\partial H}{\partial t}+\frac{\partial Q}{\partial x} \frac{c^{2}}{g A}=0$

By the same way, the momentum equation, i.e. Eq. (2) can be simplified and written in terms of discharge and piezometric head as follows;

$$
\frac{\partial H}{\partial x}+\frac{1}{g A} \frac{\partial Q}{\partial t}+\frac{f Q|Q|}{2 g D A^{2}}=0
$$

\section{Implicit Finite Difference Solution Method}

The computer program WHAMO uses the implicit finite-difference technique but converts its equations to a linear form before it solves the set of equations (Fitzgerald and Van Blaricum [8]). The solution space is discretized into the $\mathrm{x}-\mathrm{t}$ plane, so that at any point on the grid $(x, t)$ there is a certain $H$ and $Q$ for that point, $H(x, t)$ and $Q(x, t)$ as shown in Fig. (1).

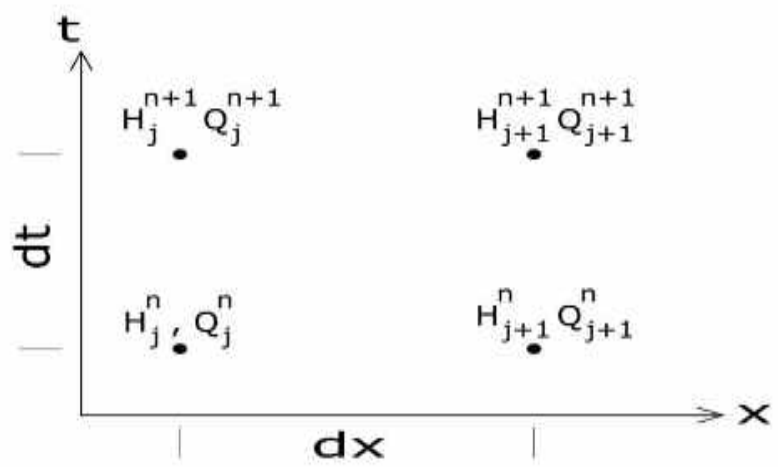

Fig. 1. The finite difference grid.

The momentum equation and the continuity equation can be represented in a short form by introducing the following coefficients for the known values in a system;

$$
\begin{aligned}
& \alpha_{j}=\frac{2 \Delta t c_{j}^{2} \theta}{g A_{j} \Delta x_{j}} \\
& \beta_{j}=\left(H_{n, j+1}+H_{n, j}\right)+\frac{(1-\theta)}{\theta} \alpha_{j}\left(Q_{n, j}-Q_{n, j+1}\right)
\end{aligned}
$$

Journal of Engineering Sciences, Assiut University, Faculty of Engineering, Vol. 41, No. 6, November, 2013, E-mail address: jes@aun.edu.eg 
Moustafa S. Darweesh et al., Analysis of different protection methods against water hammer on water supply network (case study-Assiut city network), pp. $2021-2035$

$$
\begin{aligned}
& \gamma_{j}=\frac{\Delta x_{j}}{2 g \theta A_{j} \Delta t} \\
& \delta_{j}=\frac{(1-\theta)}{\theta}\left(H_{n, j}-H_{n, j+1}\right)+\gamma_{j}\left(Q_{n, j}+Q_{n, j+1}\right) \\
& \quad-\frac{\Delta x_{j} f_{j}}{4 g \theta D_{j} A^{2}}\left(Q_{n, j}\left|Q_{n, j}\right|+Q_{n, j+1}\left|Q_{n, j+1}\right|\right)
\end{aligned}
$$

Where $\theta$ is a weighing factor included for numerical stability. All parameters for the coefficients should be known from the properties of the pipe or the values of head and flow at the previous time step. With the coefficients, the momentum and continuity equations of the $\mathrm{j}^{\text {th }}$ segment of the pipe become as given by Batterton [5] as follows;

$$
\begin{aligned}
& \text { Momentum: }-H_{n, j+1}+H_{n+1, j+1}+\gamma_{j}\left(Q_{n+1, j}+Q_{n+1, j+1}\right)=\delta_{j} \\
& \text { Continuity: } H_{n, j+1}+H_{n+1, j+1}+\alpha_{j}\left(Q_{n+1, j+1}-Q_{n+1, j}\right)=\beta_{j}
\end{aligned}
$$

Now, with equations for the all links and nodes in the system, the initial and boundary conditions, a matrix of the linear system of equations can be set up to solve for head and flow everywhere, simultaneously, for the first time step. The process is repeated for the next time step, and again for the next step until the specified end of the simulation.

\section{Case Study}

The analysis of transient flow was performed for Assiut city water supply network (ACWSN). There are two sources of water feeding the network, from which the water is pumped into the network, at node 27 and node 28 (Fig. 2). Elevations of all the network junctions are assumed to be the same at level zero. Average base demands for the different junction are shown in Table (1). The distribution system shown in Fig. (2) is composed of 29.6 Km of different diameter pipelines with lengths of P1 through P35 as shown in Table (2). Shown in Fig. (2) are the pipe and joint numbering Pi and Ji respectively and also, the flow directions for normal operation conditions. All pipes are High Density Polyethylene (HDPE) and the head loss in each pipe is computed using Darcy-Weisbach formula. The results are performed for three scenarios; the first, is the normal operation of pump 36 and failure of pump 37, the second, is the normal operation of pump 37 and failure of pump 36, and finally failure of pumps 36 and 37 together. For the previous three scenarios, the pipe network is studied with steady normal case (pumps 36 and 37 working normally), without any protection against water hammer phenomenon, and is studied with an transient protection device(s) such as non-return valve, open surge tank, air chamber and pressure relief valve (PRV).

Journal of Engineering Sciences, Assiut University, Faculty of Engineering, Vol. 41, No. 6, November, 2013, E-mail address: jes@aun.edu.eg 
Moustafa S. Darweesh et al., Analysis of different protection methods against water hammer on water supply network (case study-Assiut city network), pp. $2021-2035$

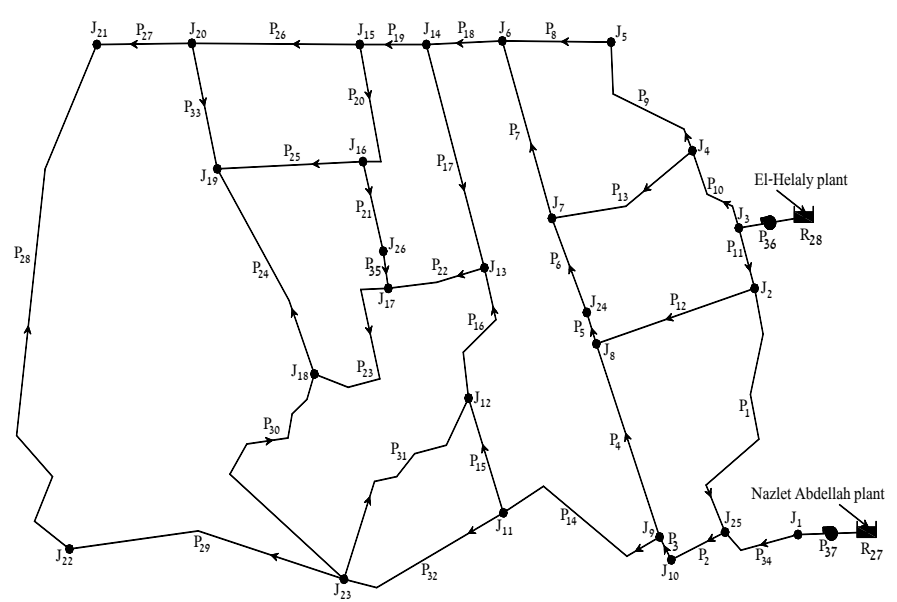

Fig. 2. Pipes, nodes numbering, pumps, sources and flow directions for normal operation condition of Assiut pipe network for pumps 36 and 37.

Table 1.

Average base demands for the different junction nodes.

\begin{tabular}{|c|c|c|c|c|c|c|c|c|c|c|c|c|c|}
\hline Node number & 1 & 2 & 3 & 4 & 5 & 6 & 7 & 8 & 9 & 10 & 11 & 12 & 13 \\
\hline $\begin{array}{c}\text { Average base } \\
\text { demand } \\
\text { (Lit./s) }\end{array}$ & 0.0 & 69 & 0.0 & 72 & 41 & 45 & 72 & 64 & 32 & 32 & 64 & 98 & 86 \\
\hline Node number & 14 & 15 & 16 & 17 & 18 & 19 & 20 & 21 & 22 & 23 & 24 & 25 & 26 \\
\hline $\begin{array}{c}\text { Average base } \\
\text { demand } \\
\text { (Lit./s) }\end{array}$ & 45 & 19 & 36 & 75 & 110 & 69 & 53 & 90 & 90 & 128 & 0.0 & 45 & 0.0 \\
\hline
\end{tabular}

Table 2.

Lengths and diameters of the different pipes.

\begin{tabular}{|c|c|c|c|c|c|}
\hline $\begin{array}{c}\text { Pipe } \\
\text { number }\end{array}$ & $\begin{array}{c}\text { Length } \\
(\mathbf{m})\end{array}$ & $\begin{array}{c}\text { Diameter } \\
(\mathbf{m m})\end{array}$ & $\begin{array}{c}\text { Pipe } \\
\text { number }\end{array}$ & $\begin{array}{c}\text { Length } \\
(\mathbf{m})\end{array}$ & $\begin{array}{c}\text { Diameter } \\
(\mathbf{m m})\end{array}$ \\
\hline P1 & 1600 & 800 & P19 & 300 & 600 \\
\hline P2 & 300 & 1000 & P20 & 600 & 400 \\
\hline P3 & 600 & 1000 & P21 & 300 & 500 \\
\hline P4 & 900 & 500 & P22 & 600 & 400 \\
\hline P5 & 200 & 500 & P23 & 600 & 400 \\
\hline P6 & 300 & 500 & P24 & 950 & 400 \\
\hline P7 & 1400 & 500 & P25 & 950 & 300 \\
\hline P8 & 1100 & 800 & P26 & 1200 & 600 \\
\hline P9 & 500 & 800 & P27 & 400 & 600 \\
\hline
\end{tabular}

Journal of Engineering Sciences, Assiut University, Faculty of Engineering, Vol. 41, No. 6, November, 2013, E-mail address: jes@aun.edu.eg 
Moustafa S. Darweesh et al., Analysis of different protection methods against water hammer on water supply network (case study-Assiut city network), pp. $2021-2035$

\begin{tabular}{|c|c|c|c|c|c|}
\hline $\begin{array}{c}\text { Pipe } \\
\text { number }\end{array}$ & $\begin{array}{c}\text { Length } \\
(\mathbf{m})\end{array}$ & $\begin{array}{c}\text { Diameter } \\
(\mathbf{m m})\end{array}$ & $\begin{array}{c}\text { Pipe } \\
\text { number }\end{array}$ & $\begin{array}{c}\text { Length } \\
(\mathbf{m})\end{array}$ & $\begin{array}{c}\text { Diameter } \\
(\mathbf{m m})\end{array}$ \\
\hline P10 & 800 & 800 & P28 & 2650 & 600 \\
\hline P11 & 150 & 800 & P29 & 2100 & 600 \\
\hline P12 & 850 & 500 & P30 & 1500 & 400 \\
\hline P13 & 1100 & 500 & P31 & 1600 & 400 \\
\hline P14 & 500 & 1000 & P32 & 1500 & 800 \\
\hline P15 & 750 & 500 & P33 & 700 & 400 \\
\hline P16 & 850 & 500 & P34 & 500 & 1200 \\
\hline P17 & 1000 & 500 & P35 & 150 & 500 \\
\hline P18 & 100 & 800 & & & \\
\hline
\end{tabular}

\section{Results and Discussions}

To investigate the water hammer effect on the transient pressure heads at points representing different places on the network, point J17 represents the middle point of the network and point $\mathrm{J} 2$ represents the nearer point from the pumps while point $\mathrm{J} 21$ represents the far away point from the pumps. At each point, the transient change of piezometric pressure heads is examined. The investigations are based on the comparison between the use of different protection devices and no protection case with the three studied scenarios of pumps shut down. Steady normal operations are included for the comparison. Figure 3 shows the changes of pressure heads with the time at node $\mathrm{J} 17$ for the three scenarios and the network has no protection devices. It is seen that the shutting down of pump 36 or 37 only lowering the pressure from $57 \mathrm{~m}$ of water to be approximately 5 and $11 \mathrm{~m}$, respectively while it reaches to $-35 \mathrm{~m}$ of water for shutting down of pumps 36 and 37 together. Whereas shutting down of pumps 36 and 37 together lowers the pressure to be negative at this point for unprotected case. The use of different protection devices with these scenarios is studied. Shown in Fig. 4 is a comparison between the effect of the use of these devices on the pressure head. It is seen that the pressure lowered from $57 \mathrm{~m}$ (steady case) to $-12 \mathrm{~m}$ of water for using NRV only or using NRV with PRV together. For using NRV with open surge tank, the pressure head harmony decreases without fluctuations to $41 \mathrm{~m}$ of water and to $31 \mathrm{~m}$ of water for using NRV with air chamber after 300 seconds.

For the nearer points from the pumps, Fig. 5 is drawn to show the variations of pressure heads with the time at node $\mathrm{J} 2$ for the studied scenarios and without any protection case. It is shown from the figure that, the shutting down of pump 37 only decreases the head from $59 \mathrm{~m}$ to $31 \mathrm{~m}$, and for the shutting down of pump 36 alone the reduction in the head reached to $14 \mathrm{~m}$, while for the shutting down of pumps 36 and 37 together the pressure head reduces to be $-6 \mathrm{~m}$ of water. For protection cases, the pressure reaches to $-3 \mathrm{~m}$ of water for using NRV or NRV with PRV together. For using NRV with open surge tank, the pressure head regularly decreases without fluctuations to $43 \mathrm{~m}$ of water and to $34 \mathrm{~m}$ of water for NRV with air chamber after 300 seconds as shown in Fig. 6.

To show the water hammer effect at the far away point from the pumps, the changes of pressure heads with the time at node $\mathrm{J} 21$ for the previously scenarios and the network has

Journal of Engineering Sciences, Assiut University, Faculty of Engineering, Vol. 41, No. 6, November, 2013, E-mail address: jes@aun.edu.eg 
Moustafa S. Darweesh et al., Analysis of different protection methods against water hammer on water supply network (case study-Assiut city network), pp. $2021-2035$

no protection devices are shown drawn as in Fig. 7. It is noticeable that the shutting down of pump 36 or 37 only lowering the pressure head from $57 \mathrm{~m}$ of water to be approximately 7 and $4 \mathrm{~m}$, respectively while shutting down the both pumps together lowers the pressure head to $-43 \mathrm{~m}$. Shutting down of pumps 36 and 37 together lowers the pressure to negative at this point from $59 \mathrm{~m}$ of water to be approximately $-43 \mathrm{~m}$ of water for unprotected case, and to -17 m of water when using NRV or with PRV together. By using NRV with open surge tank, the pressure head gradually decreases without fluctuations to $31 \mathrm{~m}$ of water and to $16 \mathrm{~m}$ of water for using NRV with air chamber after 300 seconds as shown in Fig. 8.

Finally, from the results shown in Figs. (3 to 8), it is evident that, the appropriate protection method for the pipe network is the using of air chamber or open surge tank with non-return valve. This because, they absorb the water hammer and decrease the pressure heads gradually to reach the final stable pressure head without any waves and the maximum pressure heads act as the steady case. In addition, they have minimum percent of deviation in pressure heads than the normal steady case, compared to other protection methods. Also, the figures show that the sudden shut down of the pumps 36 and 37 together has the large effect on the transient pressure heads than the shut down of any of them only.

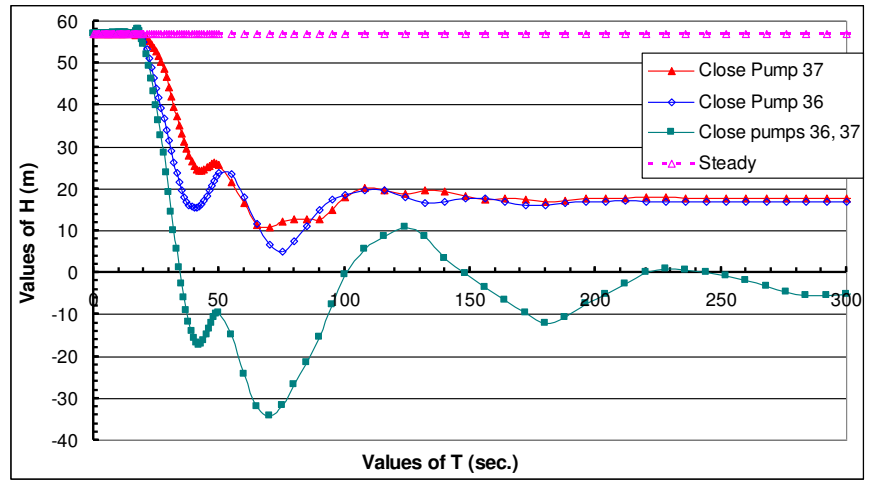

Fig. 3. Changes of pressure heads with time due to different scenarios at node J17 for unprotected case.

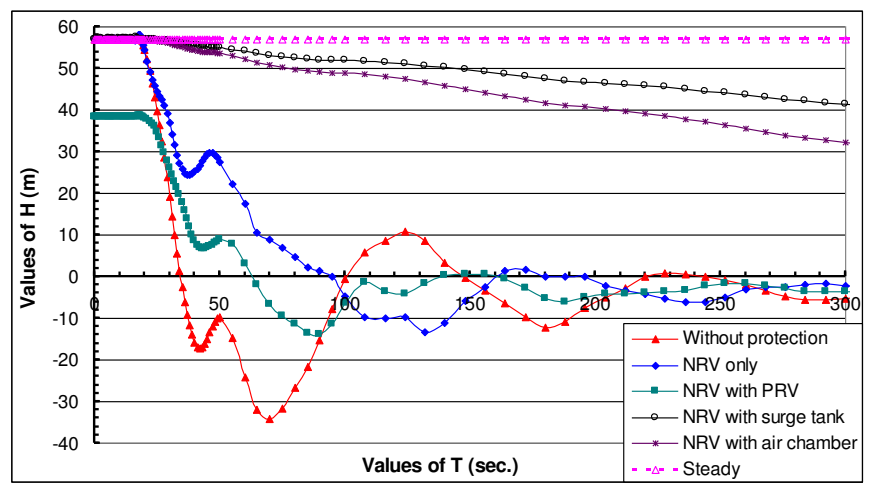

Fig. 4. Changes of pressure heads with time at node $\mathrm{J} 17$ due to close pumps 36 and 37 together and using different protection methods.

Journal of Engineering Sciences, Assiut University, Faculty of Engineering, Vol. 41, No. 6, November, 2013, E-mail address: jes@aun.edu.eg 
Moustafa S. Darweesh et al., Analysis of different protection methods against water hammer on water supply network (case study-Assiut city network), pp. $2021-2035$

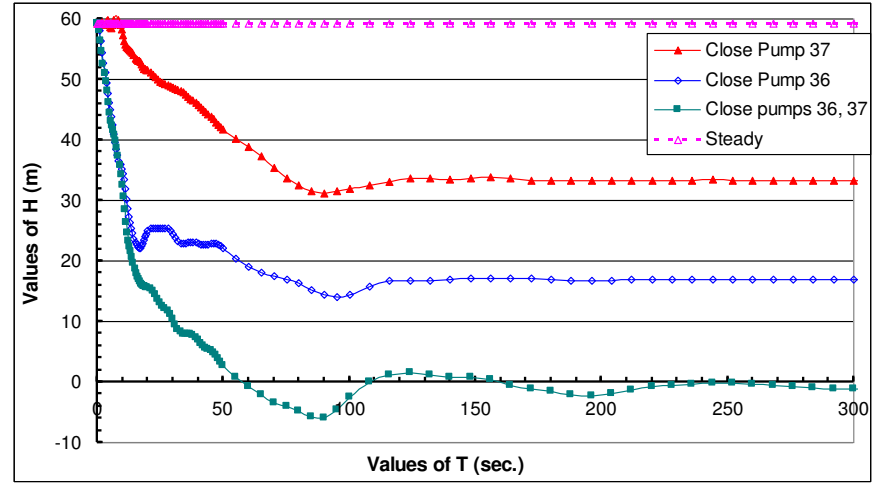

Fig. 5. Changes of pressure heads with time due to different scenarios at node $\mathrm{J} 2$ for unprotected case.

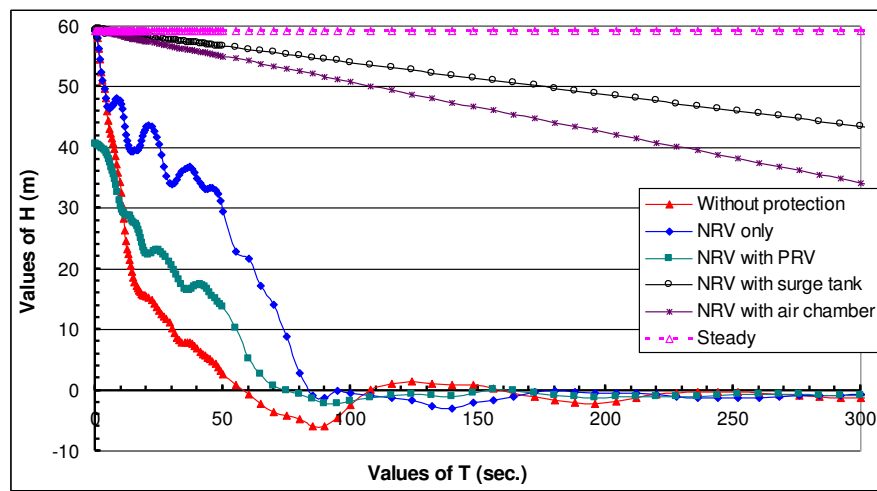

Fig. 6. Changes of pressure heads with time at node $\mathrm{J} 2$ due to close pumps 36 and 37 together and using different protection methods.

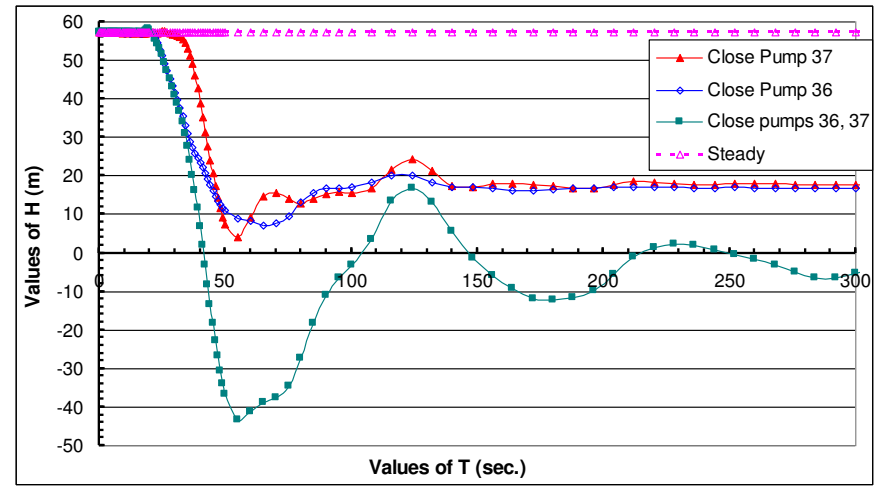

Fig. 7. Changes of pressure heads with time due to different scenarios at node $\mathrm{J} 21$ for unprotected case.

Journal of Engineering Sciences, Assiut University, Faculty of Engineering, Vol. 41, No. 6, November, 2013, E-mail address: jes@aun.edu.eg 
Moustafa S. Darweesh et al., Analysis of different protection methods against water hammer on water supply network (case study-Assiut city network), pp. $2021-2035$

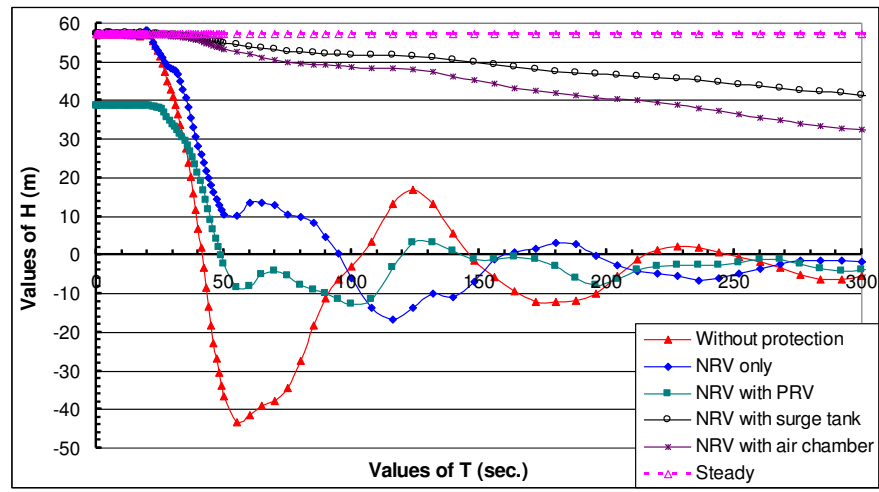

Fig. 8. Changes of pressure heads with time at node J21 due to close pumps 36 and 37 together and using different protection methods.

To illustrate the influence of water hammer on the transient flows through pipelines representing different places on the network, pipeline P22 represents the middle pipe of the network and pipeline P12 represents the nearer pipe from the pumps while pipeline P28 represents the far away pipe from the pumps. At each element, the transient change of discharges is examined. The investigations are based on the comparison between the use of different protection devices and no protection case with the three studied scenarios of pumps shut down. Steady normal operations are included for the comparison. Negative sign means that the discharge is in the reverse direction in comparison with that of normal operation conditions. Figure 9 shows the changes of flow rates with the time through pipe P22 for the three scenarios and the network has no protection devices. It is seen that the shutting down of pump 36 or 37 only or both together changes the discharge directions and values by different percents, the higher values are from $82 \mathrm{~L} / \mathrm{sec}$. to approximately $-25,-77$ and $-166 \mathrm{~L} / \mathrm{sec}$., respectively. Also, the first and third shutting down scenarios, increase the discharge to be $+170 \mathrm{~L} / \mathrm{sec}$.

For the nearer pipelines from the pumps, Fig. 10 is drawn to show the variations of discharges with the time through pipe P12 for the studied scenarios of pumps shutting down and without any protection case. It is shown from the figure that, the shutting down of pump 36 only or the two pumps together, changes the discharge directions and values by different percents, the higher values are from $126 \mathrm{~L} / \mathrm{sec}$. to approximately-357 and -296 $\mathrm{L} / \mathrm{sec}$., respectively but for the shutting down of pump 37 only the transient discharge increases to $+531 \mathrm{~L} / \mathrm{sec}$.

To investigate the water hammer effect at the far away pipelines from the pumps, the changes of flow rates with the time through pipeline P28 for the previously mentioned scenarios of pumps shutting down and the network has no protection devices are shown in Fig. 11. The figure shows that the shutting down of pump 37 only or the two pumps together, changes the discharge directions and values by different percents, the higher value is from 46 to nearly $-202 \mathrm{~L} / \mathrm{sec}$. Also, the shutting down of pump 36 only or the both pumps together, increase the discharge to +489 and $+606 \mathrm{~L} / \mathrm{sec}$., respectively.

Journal of Engineering Sciences, Assiut University, Faculty of Engineering, Vol. 41, No. 6, November, 2013, E-mail address: jes@aun.edu.eg 
Moustafa S. Darweesh et al., Analysis of different protection methods against water hammer on water supply network (case study-Assiut city network), pp. $2021-2035$

Figures $(12,13$ and 14) show the effect of using different protection devices on the transient flow through the pipes of the studied network. The figures are drawn for the case of shutting down of both pumps. It is seen from the figures that for all the selected pipes and for protecting the pipes by using non-return valve only or NRV with pressure relief valve, the behaviors of flow fluctuations are same. Also, the cases of using non-return valve with open surge tank or with air chamber, the discharge values and direction remain close to the values of steady operation with very small fluctuations compared to the other protection methods.

In general, from Figs. (9 to 14) it is evident that, the best protection device on flow through the pipe network from the water hammer harm is the using of air chamber or open surge tank with non-return valve together. This due to the deviation in the discharge from the normal case is harmony to reach the final steady discharge without any waves or fluctuations. Also, the figures show that the final stable discharges after 250 seconds from hammering through the pipelines, for all protection devices and unprotected case are equals and are the same of the normal operation discharges.

It is noticeable from the previous discussions that, the most affected points and pipes by shutting down the pumps, are the nearest points or pipes from the pump where they have high fluctuations. Also, the time taken by the water hammer wave to dissipate and reach stable state for the nearest points or pipes to the shutting down pump is longer than the case of the far points or pipes. The discussions show that, probably the middle points or pipes have large effect than the end points or pipes. This may due to the water takes longer paths to reach middle part of the network than the end part, consequently takes longer time which leads to have small fluctuation and less water hammer wave time than the far points or pipes.

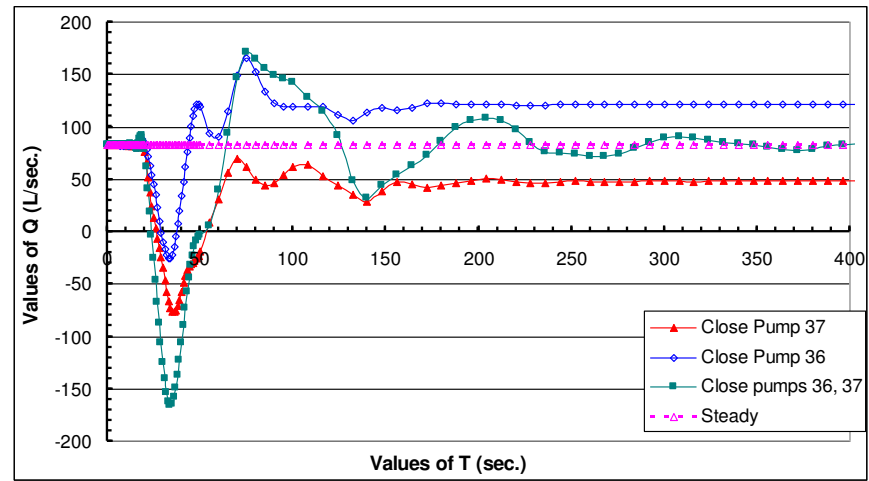

Fig. 9. Changes of discharges with time due to different scenarios through pipe P22 for unprotected case.

Journal of Engineering Sciences, Assiut University, Faculty of Engineering, Vol. 41, No. 6, November, 2013, E-mail address: jes@aun.edu.eg 
Moustafa S. Darweesh et al., Analysis of different protection methods against water hammer on water supply network (case study-Assiut city network), pp. 2021 - 2035

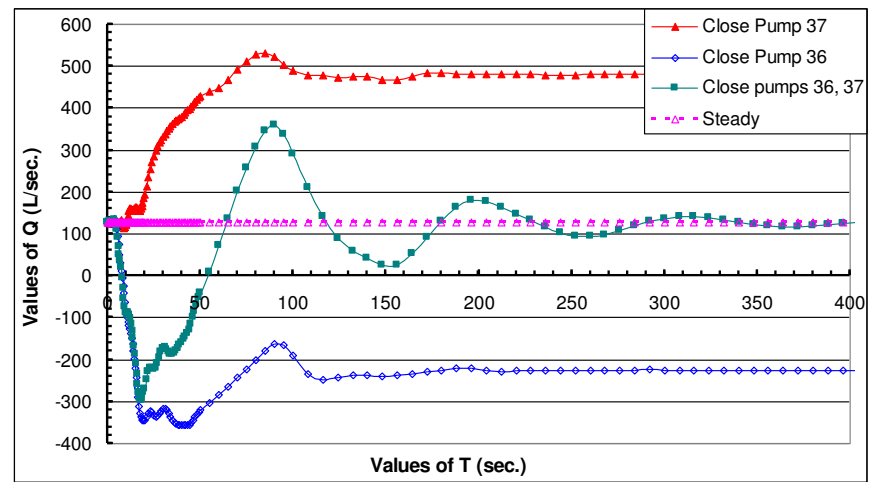

Fig. 10. Changes of discharges with time due to different scenarios through pipe P12 for unprotected case.

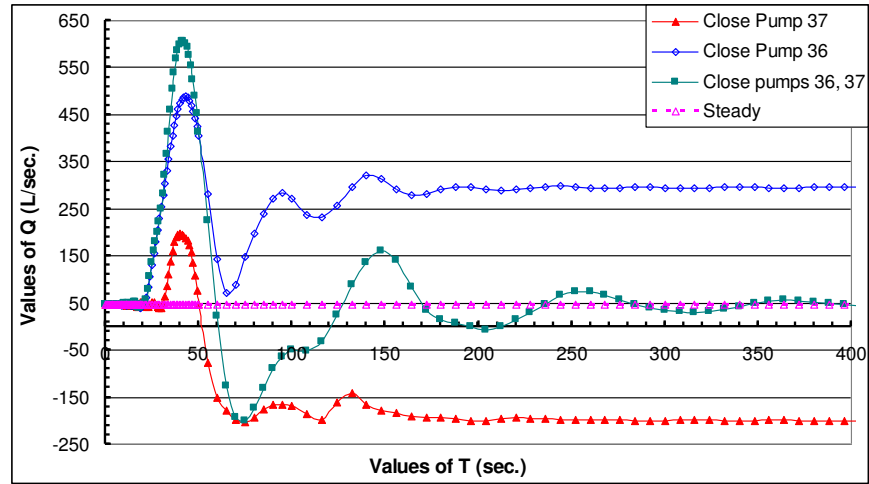

Fig. 11. Changes of discharges with time due to different scenarios through pipe P28 for unprotected case.

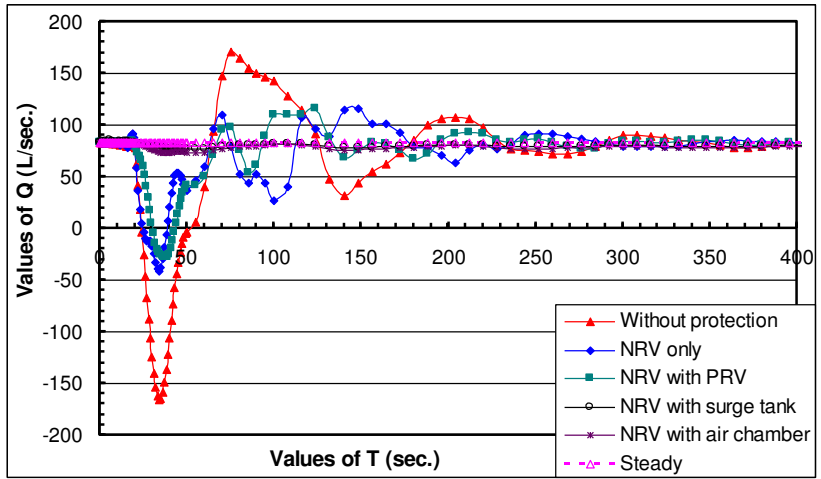

Fig. 12. Changes of discharges through pipe P22 with time due close pumps 36 and 37 together and using different protection methods.

Journal of Engineering Sciences, Assiut University, Faculty of Engineering, Vol. 41, No. 6, November, 2013, E-mail address: jes@aun.edu.eg 
Moustafa S. Darweesh et al., Analysis of different protection methods against water hammer on water supply network (case study-Assiut city network), pp. 2021 - 2035

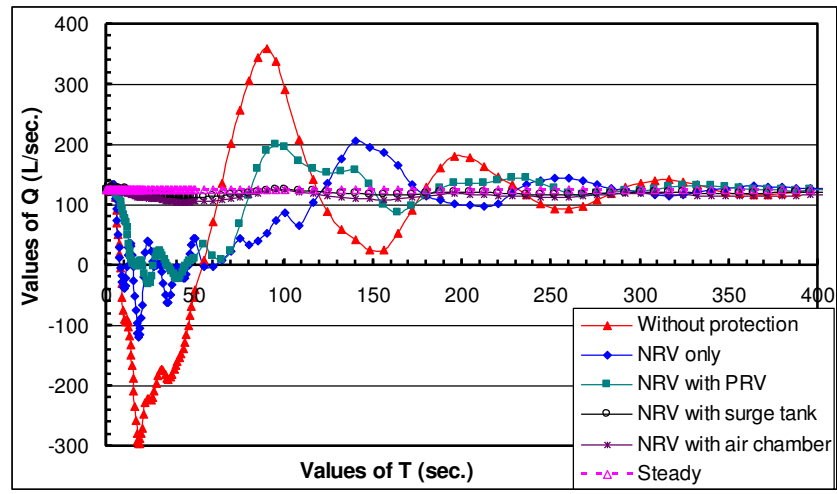

Fig. 13. Changes of discharges through pipe P12 with time due close pumps 36 and 37 together and using different protection methods.

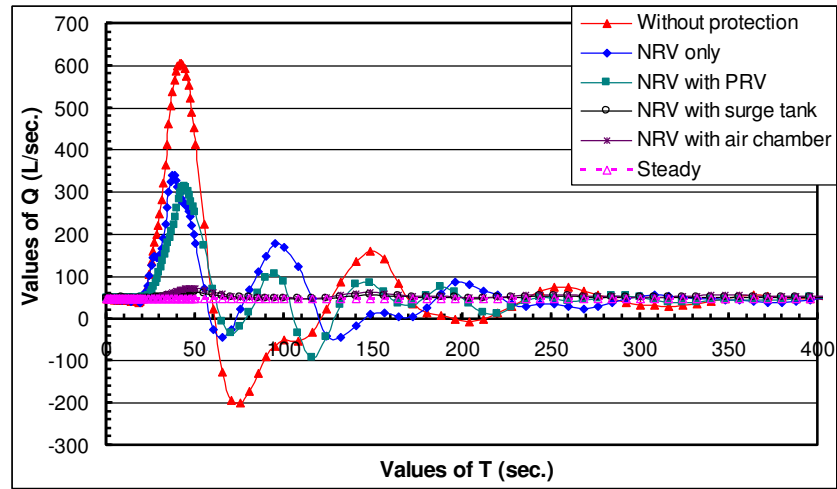

Fig. 14. Changes of discharges through pipe P28 with time due close pumps 36 and 37 together and using different protection methods.

\section{Conclusions}

Based on the numerical results of WHAMO program for transient flow in Assiut city water supply network with the studied scenarios, it is found that:

1. Using non-return valve with open surge tank or with air chamber have the same effect and protect the pipe network from negative pressures as well as high pressures and high flow fluctuations.

2. Although using PRV with non-return valve protect the pipe network from extreme pressures, it has high fluctuations for along time.

3. Using non-return valve only doesn't have a great effect on the maximum pressure head than the normal case and protects the network from the more low pressures resulting from the water hammer than without the protection case.

4. For all protection methods, the protection of the pipe network from the extremes of water hammer phenomenon increases the water hammer wave period.

Journal of Engineering Sciences, Assiut University, Faculty of Engineering, Vol. 41, No. 6, November, 2013, E-mail address: jes@aun.edu.eg 
Moustafa S. Darweesh et al., Analysis of different protection methods against water hammer on water supply network (case study-Assiut city network), pp. $2021-2035$

5. The sudden shut down of the pumps 36 and 37 together has the large effect on the pressure heads than the shut down of any of them only.

\section{References}

[1] Abd El-Gawad, S. M., "Water Hammer Analysis for the Pipeline Ahmed Hamdi Tunnel, AbuRadis”, Engng. Res. Jour., Vol. 6, pp. 40-54, (1994).

[2] Abozeid, G., Mohamed, H. I., and Hassan, I. M., "Studying of Water Hammer Phenomenon Caused by Sudden Variation of Water Demand at Water Supply Pipes Network", Jour. of Eng. Science, Assiut University, Vol. 40, No. 2, March, pp. 353-366, (2012).

[3] Ali, N.A., Mohamed, H.I., El-Darder, M.E., and Mohamed, A.A., "Analysis of transient flow phenomenon in pressurized pipes system and methods of protection", Jour. of Eng. Science, Assiut University, Vol. 38, No. 2, pp. 323-342, (2010).

[4] Al-Khomairi, A. M., "Use of the Steady-State Orifice Equation in the Computation of Transient Flow Through Pipe Leaks", The Arabian Jour. for science and Eng., Vol. 30, N. IB, PP. 33-45, (2005).

[5] Batterton, S., "Water Hammer: An analysis of plumbing systems, intrusion, and pump operation", Thesis submitted to the Faculty of the Virginia Polytechnic Institute and State University in partial fulfillment of the requirements for the degree of Master of Science in Civil Eng., pp. 147, (2006).

[6] Chaudhry, H. M. and Yevjevich, V., "Closed-Conduit Flow", water resources publications, P.O. Box 2841, Littleton, Colorado 80161, U.S.A., pp. 416, (1981).

[7] Choon, T., W., Aik, L., K., Aik, L., E., and Hin, T., T., "Investigation of Water Hammer Effect Through Pipeline System", International J. on Advanced Science Eng. Information Technology, ISSN: 2088-5334, Vol. 2, No. 3, pp. 48-53, (2012).

[8] Fitzgerald, R. and Van Blaricum, V. L., "Water Hammer and Mass Oscillation (WHAMO) 3.0 user's manual", (1998).

[9] Fouzi, A. and Ali, F., "Comparative study of the phenomenon of propagation of elastic waves in conduits", Proceed. of The World Congress on Eng., July 6-8, Vol. III, London, U.K, (2001).

[10] Friedman, M., Radder, L., Harrison, S., Howie, D., and Britton, M., "Verification and Control of Pressure Transients and Intrusion in Distribution Systems", Awwa Research Foundation (AwwaRF), (2004).

[11]Kim, S. H., "Impulse Response Method for Pipeline Systems Equipped with Water Hammer Protection Devices", Jour. of Hyd. Eng., Vol. 134, No. 7, pp. 961-969, (2008).

[12] Lohrasbi, A. R. and Attarnejad, R., "Water Hammer Analysis by Characteristic Method", American J. of Engineering and Applied Sciences, Vol. 1, No. 4, pp. 287-294, (2008).

[13] Magzoub, M. A. E., and Kwame, S. O. A., "Hydraulic Transient in a Pipeline Using Computer Model to Calculate and Simulate Transient", M. Sc. Thesis, Division of Water Resources Engineering, Dept. of Building and Environmental Technology, Lund Univ., Sweden, January, (2007).

[14] Mohamed, H. I., "Parametric Study for the Water Hammer Phenomenon in Pipelines", $1^{\text {st }}$ Int. Conf. of civil Eng. Science, ICCES1, Assiut, Egypt, 7-8 Oct., Vol. II, pp. 1-12, (2003).

[15] Mohamed, H.I., and Ali A. M. Gad, "Effect of Pipes Networks Simplification on Water Hammer Phenomenon", Jour. of Eng. Science, Assiut University, Vol. 40, No. 6, pp. 16251647, (2012).

[16] Nitescu, C. S., Constantin, A., and Stănescu, M., "Hydraulic study on pumping stations equipped with air chamber mounted next to the pump", International Journal of Mathematical Models and Methods in Applied Sciences, Vol. 5, Issue 8, pp. 1318-1325, (2011).

[17] Parmakian, J., "Water Hammer Analysis", Dover Publications, New York, (1963).

Journal of Engineering Sciences, Assiut University, Faculty of Engineering, Vol. 41, No. 6, November, 2013, E-mail address: jes@aun.edu.eg 
Moustafa S. Darweesh et al., Analysis of different protection methods against water hammer on water supply network (case study-Assiut city network), pp. $2021-2035$

[18] Simpson, A. R. and Wu, Z. Y., "Computer Modelling of Hydraulic Transient in Pipe Networks and Associated Design Criteria", MODSIM97, International Congress on Modelling and Simulation, Modelling and Simulation Society of Australia, Hobart, Tasmania, Australia, (1997).

[19] Stephenson, D., "Simple Guide for Design of Air Vessels for Water Hammer Protection of Pumping Lines", Jour. of Hyd. Eng., Vol. 128, No. 8, pp. 792-797, (2002).

[20] Watters, G. Z., Jeppson, R. W. and Flammer, G. H., "Water Hammer in PVC and Reinforced Plastic Pipe", Jour. of Hydr. Division, Vol. 102, No. 7, pp. 831-843, (1976).

\section{"دراسة طرق الحماية المختلفة من المطرقة المائية على شبكات توزيع المياه

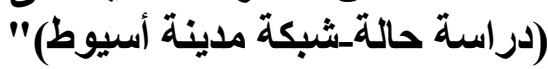

الملخص العربى

ظاهرة الطرث المائي هي حدوث تغير فجائي لسرعة السريان داخل الأنبوب وتحدث غالبا نتيجة اغلاق

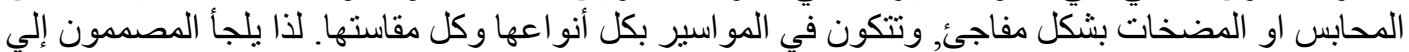

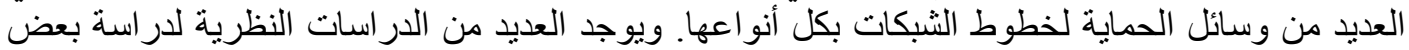

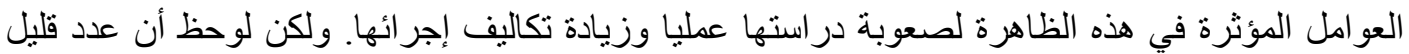

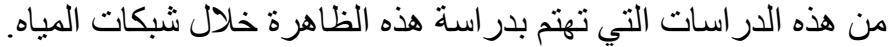

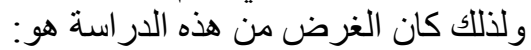

1. در اسة تأثير القفل المفاجئ لأحد أو كل الطلمبات المغذية للشبكة مياه الشرب لمدينة أسيوط على التغير

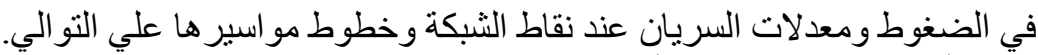
2. تحديد أي من هذه الطلمبات أكثر خطورة على الضغوط ومعدلات السريان عند نقاط النبكة التبكة وخطوط

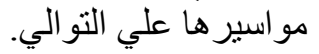

3. در اسة وسائل وطرق ولئ الحماية المختلفة ونأثير ها على ظاهرة المطرقة المائية.

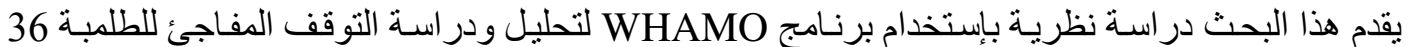

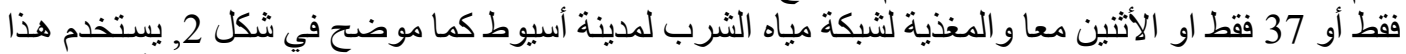
البرنامج طريقة الفروقات المحدودة لحل معادلتي الاستمر ارية والتغير في كمية الحركة. كان من النية أهم النتائج

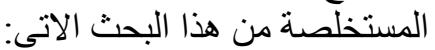

1. استخدام خزان التوازن أو خزان الهواء مع محبس عدم الرجوع لهما لفس التأثنير حيث تتم حماية الثبكة

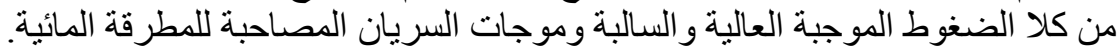

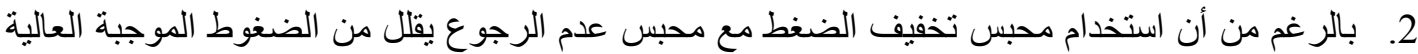

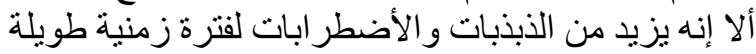

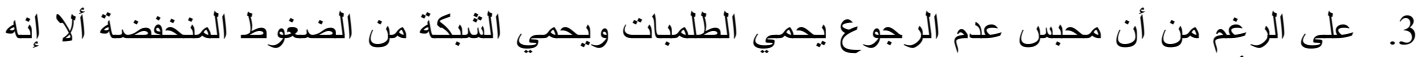

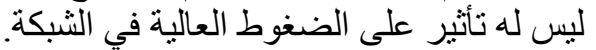

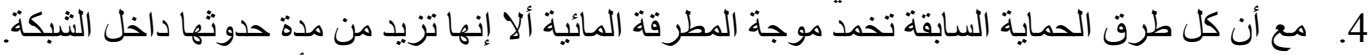

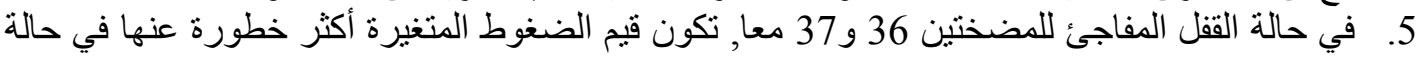
قفل إحدى المضختين على حده.

Journal of Engineering Sciences, Assiut University, Faculty of Engineering, Vol. 41, No. 6, November, 2013,E-mail address: jes@aun.edu.eg 